\title{
LEARNING STRATEGIES WITH DIGITAL GAMES IN THE UNIVERSITY CONTEXT: MULTIPLE CASE STUDY
}

\author{
F. Pimentel ${ }^{1}$, M. M. Marques ${ }^{2}$ \\ ${ }^{1}$ Federal University of Alagoas (BRAZIL) \\ ${ }^{2}$ University of Aveiro (PORTUGAL)
}

\begin{abstract}
Learning strategies are procedures used to facilitate learning. They can involve cognition or metacognition. Cognitive strategies are focused on efficient storage and retrieval of information. They may appear spontaneously but can also be trained. Metacognition involves thinking about cognition, behaviour, and the learning process itself, including self-regulation of learning. Metacognitive strategies are procedures that each individual use to plan, monitor and regulate their own thinking and learning.

Technological advances have provided great possibilities for Education, namely in what regards the use of digital resources in educational activities or environments. In the context of Higher Education, empirical research seeks to clarify which digital technologies, including digital games, are associated with educational processes of teaching and learning. As digital games are present in the life of part of university students, it is considered relevant to empirically analyse possibilities of learning through digital games.
\end{abstract}

Based on studies on learning strategies that can be mobilized in digital games, this research in progress is being conducted with the purpose of clarifying the following research question: which cognitive and metacognitive learning strategies are mobilized through digital games in the context of university students? The objective is to analyse how cognitive and metacognitive learning strategies are enhanced through digital games in the context of university students. A qualitative empirical research is adopted, with a Multiple Case Study approach, involving two public Higher Education institutions, one in Brazil and another in Portugal. Data collection will be performed using questionnaire, interview, and observation during an online game, for data triangulation. In this paper we briefly present the construction and validation of the data collection questionnaire. Data analysis includes descriptive statistics with graphic representation and interpretation, through sequential analyse and coding. A profile of the reality will be drawn through this study, to understand the culture and its possible modification with the insertion of digital games in the learning processes.

It is hoped that through this investigation it will be possible to characterize how digital games are used in the context of university students; as well as understanding the changes in the digital culture paradigm with the use of digital games in educational contexts. With these steps, the objective is to relate how cognitive and metacognitive strategies can be enhanced in the university context.

Keywords: Education, Digital games, Cognitive learning strategies, Metacognitive learning strategies, Higher education.

\section{INTRODUCTION}

Technological advances have enabled the use of diversified resources in educational activities or environments. As digital games are present in the life of part of university students [1,2], one of the themes of empirical research in Higher Education contexts focuses on digital games as cultural artifacts that can be associated with educational processes $[3,4,5,6,7]$.

The use of digital games in Higher Education contexts presents both advantages and challenges for teaching and student practice, providing a new culture about media, awakening new competences and skills in academic daily life. The possibility of building new knowledge in the different educational environments and spaces arises; since the implementation of digital games can transform the concept of teaching to meet the demand of the computerization era, incorporating technology in Education in an effective way.

Based on studies on learning strategies that can be mobilized in digital games, it is intended, with this study, to clarify how cognitive and metacognitive learning strategies are mobilized through digital games in the context of university students. The chosen theme dialogues with the advancement of education 
permeated by digital technologies use. The study's main aim is to analyze how cognitive and metacognitive learning strategies are mobilized through digital games. In a previously carried out research [8], no studies on the subject were identified.

A qualitative empirical research is adopted, with a Multiple Case Study approach, involving two public Higher Education institutions, one in Brazil and another in Portugal. Data collection will be performed using questionnaire, interview, and observation during an online game, for data triangulation. In this paper we briefly present the construction and validation of one of the data collection instruments: the questionnaire.

With this research we sought to contribute to the progress of the Education knowledge field by reflecting on the potential of exploring digital games in educational practices, as well as on teachers' own training, as teachers may develop projects and activities integrating this type of technology. New ways of learning point out potential new ways of teaching, so teachers need to try out new approaches, even if those are out of their comfort zone. If students are using new technologies in non-formal spaces, it is up to the teacher to take up the challenge of learning how to teach with these new artifacts. This issue, of differences between formal and non-formal spaces when dealing with digital games, was highlighted in previous research [9] and deserves further empirical studies.

Follows a brief analysis of cognitive and metacognitive strategies, as well as the relationship of games with learning processes. The following section describes the main methodological options for the study and for the development of the data collection instrument, in order to present the questionnaire created. Finally, this contribution is concluded with the final considerations section, which summaries the presented work and its relevance.

\subsection{Learning strategies}

Learning strategies can be understood as the tools that the learner explores in his/her relationship with information. They are used to allow information storing and retrieving, when necessary [10,11]. Hence, learning strategies are related to the ability to learn, which can be directly modified by the way interactions between students and their teachers occur, or among students themselves. Such humanto-human interactions can influence how one individual learns, as well as those interactions that are carried out with educational objects and technologies.

Learning strategies can be classified into cognitive and metacognitive [11]. Cognitive strategies are focused on primary or basic learning. They aim to help the student to organize, elaborate and integrate the information.

Among cognitive learning strategies are the rehearsal strategies. These rehearsal strategies are marked by the repetition of the information, while the elaboration strategies aim to associate the new information with information previously learned. Organizational strategies, on the other hand, structure the information to be learned. The cognitive strategies of rehearsal and elaboration can also be understood as memory strategies [12].

Repetition strategies are the most used in formal education $[9,12]$. Children repeat the information presented to them, often without reaching an understanding or a concrete elaboration of knowledge. This repetition, which today can present itself as a negative factor for learning, is necessary, as it reinforces and consolidates learning.

Metacognition as a learning strategy can be understood as [12]: (a) the knowledge an individual can achieve about his/her own mental processes (planning actions on how to carry out an activity, monitoring and evaluation); or (b) the effect that this knowledge will have on the individual's own conduct.

Metacognitive strategies aim to manage and control the learning situation. They present themselves in situations of reflection or action [11]. Metacognition involves the ability to become aware of one's knowledge, by reflecting on it and on the factors that influence it, such as boosting or mobilizing attitudes and behaviors to improve one's own learning.

Another definition of metacognition is the ability to assess, regulate and organize mental processes about the cognitive objects that are studied to achieve a goal or objective [13]. It implies an awareness, as the individual is able to judge his/her own mental activities and, in face of this judgment, can decide on how to carry out the same activities or modify the ways of carrying out the activities.

Metacognitive strategies can be understood as modalities of metacognition and include becoming aware of three types of variables: (I) task, (II) student and (III) strategy. 


\subsection{Learning with Digital Games}

With digital technology progress, the universe of digital games creation has received significant prominence for industry and commerce [4]. In addition to commercial digital games, several universities, through research and technological development groups, are advancing in research and in serious game production, aiming at expanding teaching ways and outlining inventive learning [14].

Much of the research carried out in the educational field seeks to identify how to learn with digital games [15]. In addition to contents, players learn the exercise of autonomy, decision-making and choices, in an active perspective, different from what happens in a contextualization of the classroom based on the teaching transmission. Students' role stands out, in a revolution of the classroom, in addition to a new configuration of the school space.

Despite the assumptions [16, 17], the literature present data that should still be seen as evidence of possibilities. It is necessary that we look more and more, in the search for evidence that strengthens a critical and reflective analysis.

In addition to the educational space, it is worth mentioning that digital games have crossed the frontiers of virtual entertainment and are increasingly used in different contexts, such as in the areas of health, advertising, and marketing.

Digital Game-Based Learning (DBGL) can be understood in three different approaches: the production of digital games by the students themselves, the design and production of educational games (serious games) and the use of commercial digital games in particular teaching and learning situations. The claim that commercial games should also be used in educational contexts is gathering supporters [18].

As we argued about digital technologies, digital games should also be viewed from the perspective of culture. They are part of our daily lives, being more related to entertainment. According to the investigation by Pesquisa Game Brasil (2019), $66 \%$ of Brazilians play digital games.

In a digital game, even if the relationship between children is not direct, synchronous, and online, the characteristics, details and challenges of a game can be the subject of conversations by children anywhere in the world, which leads to a similarity between the involved children and corroborates their identity development. From a learning perspective, it is claimed that digital games enable the development of cognitive and metacognitive skills and strategies.

At this point, critical and analytical look at DGBL is needed, implying to review what we mean with learning [19]. What is sought is to discover diversified teaching strategies, without aspiring to maintain the same practices with digital technologies as the ones we already have without them. For this purpose, it is relevant to understand the context of digital games, in a Digital Culture, so that we can know how to deal with them in the classroom, in educational spaces or not.

Here is a relevant question emerges: do the Digital Culture and the culture of digital games merge? This question impels us to seek "to understand the culture of digital games and their interfaces" [20], even when we seek to understand the cultural mediations [21] that permeate the relationships around digital games.

From the theoretical assumptions, it is possible to return to the question that digital games are being used as cultural artifacts available in social contexts. Those who use digital games spontaneously, are collaboratively learning to face challenges, discovering new relationships and new ways of communication.

\section{METHODOLOGY}

Given the nature of the focus question, this study is a qualitative research [22, 23], as it seeks to reach subjective interpretations, reaching non-explicit or conscious motivations, aiming to find perceptions and understanding about the general nature of the issue in focus in this research. In this sense, for conducting the research, the approach that best contributes to the proposed analysis is the multiple case study [23].

Data collection is carried out with university students from a Brazilian university (Federal University of Alagoas) and a university in Portugal (University of Aveiro). Students duly enrolled in any higher education course at the listed institutions, who are players of digital games, and who have signed the Free and Informed Consent Term may participate in this investigation. All ethical procedures are being followed, in accordance with Brazilian and Portuguese legislation, to ensure data security and the participants' anonymity. 
Data collection comprises three techniques:

a) online questionnaire: it is being applied in order to identify how digital games are used in learning processes by university students; and also, to relate how cognitive and metacognitive strategies are mobilized through the use of digital games.

b) online interview: it will be carried out after the tabulation of the data collected through the questionnaire, with the participants that agree to proceed to the second phase of data gathering. It seeks to provide understanding on the changes in the paradigm of digital culture with the use of digital games, as well as to resolve doubts that may arise in the analysis of the questionnaire.

c) online observation: it will be developed with the participants who authorize the researcher to follow a digital online game session. It aims to collect information that can be used in the data triangulation, to identify the strategies used by the players.

Data tabulation and analysis will be supported by the graphical representation of the phenomenon (sectorized graphs, tables, and charts). The assessments will be carried out through interpretations, using sequential and coding analyzes.

Here in this work, the authors present the procedures performed for the construction and validation of the data collection instrument of the first technique (online questionnaire).

\section{RESULTS}

\subsection{The construction and validation of the data collection instrument}

From the theory, as well as in view of having identified a data collection instrument consistent with the purpose of the research under development, the process for the construction of the questionnaire is presented. The instrument is a self-administered type and addresses issues related to the objective of this study: to analyze which cognitive and metacognitive learning strategies are mobilized through digital games in the context of university students. Its development is in the form of a self-report, when the respondent himself must register the answers.

The questionnaire consists of three sections: inventory of metacognitive awareness; cognitive and metacognitive strategies in relation to digital games; and profile of the participant.

\subsubsection{Metacognitive Awareness Inventory}

The construction of the instrument started from methodological choices, which are clarified below. For the first part of the instrument, several options were possible for integrating the Metacognitive Awareness Inventory (MAI) [24], which is a validated questionnaire that makes it possible to achieve the intended results. In this sense, four options were identified:

1 to translate the original questionnaire which would imply carrying out a validation process;

2 to use the questionnaire translated and validated for Brazilian Portuguese [25];

3 to use the questionnaire translated and validated for Portuguese in Portugal [26]; or

4 to use the translated questionnaire, adapted to the universe of digital games and validated [27].

After analyzing all the options, the authors decided to use in Brazil the questionnaire translated and validated by Lima Filho and Bruni (2015) [25], and which originally appears in the thesis of Lima Filho (2013) [28], and in Portugal the version of Bártolo-Ribeiro, Simões and Almeida (2016) [26]. In both options, the instrument was translated from the MAI, and the Portuguese versions were validated in the relevant contexts, which provides security in data collection and analysis.

It is relevant to highlight that this first section of the instrument allows to identify the predominant metacognitive profiles presented on a five-point Likert scale. Thus, there are no answers that indicate patterns of the right/wrong or better/worse type.

At the end of the first part of the instrument, a guiding and conditioning question was inserted, being asked if the respondent usually plays digital games. In the positive choice, the participant is directed to the second part of the instrument. In the negative choice for the question, the participant is directed to the 3rd and last part of the instrument, which presents profile questions. 


\subsubsection{Cognitive and metacognitive strategies in relation to digital games}

The second section of the instrument was elaborated from the basic theoretical framework for this study $[9,10,12,25,28]$. In this part, the questions pointed to the reality of digital games (Table 1 ), as well as seeking to identify the relationship of participants with digital games.

This stage consists of 20 questions, and a 5-point Likert scale was used in a frequency perspective. Each item of the instrument should be answered taking into account the scale: (1) very often; (2) frequently; (3) occasionally; (4) rarely; (5) never.

Table 1: Questionnaire items - $2^{\text {nd }}$ part

\begin{tabular}{l} 
In Portuguese \\
\hline 1. Leio cuidadosamente as instruções do jogo antes de \\
começar a jogar. \\
\hline 2. Ao jogar, repito em voz alta palavras-chaves (ou as \\
ideias centrais) do jogo.
\end{tabular}

3. Faço anotações ou observações sobre o jogo. Compartilho com outros jogadores as minhas anotações sobre o jogo.

4. Participo de fóruns ou comunidades online para discutir sobre o jogo.

5. Categorizo meus jogos usando algum critério próprio ou por critérios de outros jogadores.

6. Leio resumos, resenhas, comentários, sobre os jogos que costumo jogar.

7. Assisto tutoriais sobre jogos, elaborados por outros jogadores.

8. Publico tutoriais sobre os jogos para outros jogadores.

Translation into English

1. I read the game instructions carefully before starting to play.

2. When playing, I repeat aloud the key words (or the central ideas) of the game.

3. I make notes or comments about the game. I share my notes about the game with other players.

4. I participate in forums or online communities to discuss the game.

5. I categorize my games using my own criteria or the criteria of other players.

6. I read summaries, reviews, comments, about the games I usually play.

7. I watch tutorials about games, made by other players.

8. I publish tutorials on games for other players.

9. No jogo, penso em várias maneiras de resolver uma situação e tento escolher a melhor.

9. In the game, I think of several ways to resolve a situation and I try to choose the best one.

10. Concentro-me no sentido global do jogo ao invés dos detalhes.

10. I focus on the overall sense of the game rather than the details.

11. Considero várias alternativas quando me deparo com um problema no jogo.

11. I consider several alternatives when I encounter a problem in the game.

12. Quando jogo, tento usar estratégias que deram certo no passado.

12. When I play, I try to use strategies that have worked in the past.

13. Tenho consciência dos meus talentos e minhas limitações durante o jogo.

13. I am aware of my talents and my limitations during the game.

14. Quando termino de jogar, geralmente, sei como me saí no jogo.

14. When I finish playing, I usually know how I did in the game.

15. Conscientemente foco atenção em estratégias importantes para jogar.

15. I consciously focus my attention on important strategies for playing.

16. No final do jogo, pergunto-me se haveria uma maneira mais fácil de realizar o desafio do jogo.

16. At the end of the game, I wonder if there was an easier way to carry out the game's challenge.

17. Quando jogo tenho controle sobre o quanto estou no caminho certo.

17. When I play, I have control over how much I am on the right track.

18. Uso os meus talentos intelectuais para compensar minhas limitações durante o jogo.

18. I use my intellectual talents to compensate for my limitations during the game.

19. Mudo de estratégia quando a que estou usando não está funcionando.

19. Change of strategy when the one I am using is not working.

20. Frequentemente me pergunto sobre como está meu desempenho enquanto estou realizando uma nova estratégia no jogo.

20. I often wonder how I am doing while I am using a new strategy in the game. 
After the elaboration of the second section of the instrument, the next step was its content validation. This was carried out through the analysis of judges, with the evaluative participation of eight judges, teachers, and researchers in the field of Education and with studies in the context of digital games. One was a specialist, five masters and two $\mathrm{PhDs}$ (one also with post-doctorate). With the evaluation procedure, the judges indicated whether the items of the instrument were clear, understandable, and appropriate to the target audience (higher education students).

The evaluation by judges was carried out in a meeting of the Working Group made up by part of the researchers from the Edumídia Research Group, affiliated at the Federal University of Santa Catarina. The meeting took place virtually, using Google Meet and it was divided into three consecutive moments. At first, the judges answered the survey questionnaire individually (results are presented in Table 2). It was sent through WhatsApp and its development is in the form of self-report. This moment's purpose was to allow the judges an experience as respondents of the instrument, having an initial contact, avoiding pre-judgments.

The second moment occurred right after completion of the questionnaire, when the judges received a validation questionnaire, also sent by WhatsApp. As for the questionnaire being validated, one judge considered it to be "Good" and seven other judges considered it "Very good". Regarding the understanding of the instrument, there was a $100 \%$ agreement on it is easy to understand.

The validation questionnaire, also using a five-point Likert scale, was returned to the first author after completion. The judges were asked: considering the language in the items below, and in view of the characteristics of the target population of this questionnaire, do you believe that the language of each item is sufficiently clear, understandable, and adequate for university students? At what level? Answers could vary on the scale, using the following guidance: (1) Not adequate at all; (2) Not adequate; (3) Averagely adequate; (4) Very adequate; (5) Completely adequate. The results of this judgment are shown in table 2.

Table 2: Judging of the items in relation to their clarity, understanding and adequacy.

\begin{tabular}{|c|c|c|c|c|c|}
\hline Item & $\begin{array}{c}\text { (1) } \\
\text { Not adequate at all }\end{array}$ & $\begin{array}{c}\text { (2) } \\
\text { Not adequate }\end{array}$ & $\begin{array}{c}\text { (3) } \\
\text { Averagely adequate }\end{array}$ & $\begin{array}{c}\text { (4) } \\
\text { Very adequate }\end{array}$ & $\begin{array}{c}\text { (5) } \\
\text { Completely adequate }\end{array}$ \\
\hline 1 & & & & $13 \%$ & $87 \%$ \\
\hline 2 & & & $12 \%$ & $12 \%$ & $75 \%$ \\
\hline 3 & $14 \%$ & $14 \%$ & & $14 \%$ & $57 \%$ \\
\hline 4 & & & & & $100 \%$ \\
\hline 5 & & & $25 \%$ & $25 \%$ & $50 \%$ \\
\hline 6 & & & & & $100 \%$ \\
\hline 7 & & & & $25 \%$ & $75 \%$ \\
\hline 8 & & & & $25 \%$ & $75 \%$ \\
\hline 9 & & & & & $100 \%$ \\
\hline 10 & & & $13 \%$ & $25 \%$ & $62 \%$ \\
\hline $11^{*}$ & & $14 \%$ & $14 \%$ & $14 \%$ & $57 \%$ \\
\hline 12 & & & & & $100 \%$ \\
\hline 13 & & & & $25 \%$ & $75 \%$ \\
\hline $14^{*}$ & & & & $14 \%$ & $86 \%$ \\
\hline 15 & & & $12 \%$ & $13 \%$ & $75 \%$ \\
\hline 16 & & & & $13 \%$ & $87 \%$ \\
\hline 17 & & & $13 \%$ & $25 \%$ & $62 \%$ \\
\hline 18 & & & $25 \%$ & $25 \%$ & $50 \%$ \\
\hline $19^{*}$ & & & & & $100 \%$ \\
\hline 20 & & & & $25 \%$ & $75 \%$ \\
\hline
\end{tabular}

* Items 11, 14 and 19 gained one less answer than the remaining ones. 
After completing the validation questionnaire, the judges participated in a focus group session [29], where they expressed their perceptions regarding the instrument. In this third moment of the meeting, all statements of the instrument were analyzed, item by item, adjusting for the definitive application.

Item 3 was subdivided into two items, and item 7 was excluded. This third moment of validation was concluded after the items were compared with the observations sent by the research supervisor in Brazil and Portugal, reaching a conclusion. After the three moments, the instrument validated for this research is shown in Table 3.

Table 3: Validated questionnaire items $-2^{\text {nd }}$ part

\begin{tabular}{l} 
In Portuguese \\
\hline $\begin{array}{l}\text { 1. Leio cuidadosamente as instruções do jogo antes de } \\
\text { começar a jogar. }\end{array}$ \\
\hline 2. Ao jogar, repito em voz alta palavras-chaves ou as \\
ideias centrais do jogo. \\
3. Faço anotações ou observações sobre o jogo. \\
4. Compartilho com outros jogadores as minhas \\
anotações sobre o jogo. \\
5. Leio resumos, resenhas, comentários, sobre os \\
jogos que costumo jogar. \\
6. Assisto tutoriais sobre jogos, elaborados por outros \\
jogadores.
\end{tabular}

7. Participo interagindo e discutindo em fóruns ou comunidades online sobre jogos.

8. Publico tutoriais sobre os jogos para outros jogadores.

9. No jogo, penso em várias maneiras de resolver uma situação e tento escolher a melhor.

10. Concentro-me no objetivo global do jogo.

11. Considero várias alternativas de solução quando me deparo com um problema no jogo.

12. Quando jogo, tento usar estratégias que deram certo no passado.

13. Tenho consciência dos meus talentos e minhas limitações durante o jogo.

14. Quando termino de jogar, geralmente sei como me saí no jogo.

15. Conscientemente foco minha atenção em estratégias eficientes para jogar.

16. Ao jogar pergunto-me se haveria uma maneira mais fácil de realizar o desafio do jogo.

17. Quando jogo sei o quanto estou no caminho certo.

18. Uso minhas habilidades para compensar minhas limitações durante o jogo.

19. Mudo de estratégia quando a que estou usando não está funcionando.

20. Pergunto-me como está meu desempenho ao usar uma nova estratégia no jogo.

Translation into English

1. I read the game instructions carefully before starting to play.

2. When playing, I repeat aloud keywords or the central ideas of the game.

3. I make notes or comments about the game.

4. I share my notes about the game with other players.

5. I read summaries, reviews, comments, about the games I usually play.

6. I watch tutorials about games, made by other players.

7. I participate by interacting and discussing on forums or online communities about games.

8. I publish tutorials on games for other players.

9. In the game, I think of several ways to resolve a situation and try to choose the best one.

10. I focus on the overall goal of the game.

11. I consider several alternative solutions when I encounter a problem in the game.

12. When I play, I try to use strategies that have worked in the past.

13. I am aware of my talents and of my limitations during the game.

14. When I finish playing, I usually know how I did in the game.

15. I consciously focus my attention on effective strategies for playing.

16. When playing, I wonder if there would be an easier way to carry out the game challenge.

17. When I play, I know how much I am on the right track.

18. I use my skills to compensate for my limitations during the game.

19. I change of strategy when the one I am using is not working.

20. I wonder how I am doing when using a new strategy in the game. 


\subsubsection{Participant profile}

The third section of the instrument aims to identify the respondents' profile. Initially respondents are questioned about what types of digital games he/she plays and how often, using the following scale as a reference: (1) I do not play; (2) Occasionally or (3) Often. The following options were given for the type of game: RPG, adventure, emulation, simulation, strategy, action, and puzzle, making it possible to also indicate other types. In sequence, it was asked which types of digital games the respondent usually plays the most. In addition, it is asked how long he/she plays, on average, and how often. The following options were given: 1 to 2 hours; 2 to 3 hours; 3 to 4 hours; 4 to 5 hours; more than 5 hours a day.

At the end of this profile step, other non-game related data is collected, so respondents are asked to identify the university or college they are enrolled in, as well as what area of knowledge the course in which they are enrolled fits and which period / semester they are attending. For age, the following options are presented: 18 to 22 years; 23 to 27 years; 28 to 32 years; 33 to 37 years and 38 years or more.

All ethical procedures were followed, according to Brazilian and Portuguese legislation, through the request for informed consent to the participants, guarantee of anonymity and confidentiality. This study is carried out with adult and healthy participants, capable of granting informed and free consent, having received February 5, 2021 a substantiated opinion from the Research Ethics Council (Brazil), with the reference, $4,566,901$.

\section{FINAL CONSIDERATIONS}

Studies on digital games in formal educational contexts, specifically in Higher Education, require empirical research to provide data that allows understanding the phenomenon and reflecting on these artifacts' contribution to cognitive and metacognitive development.

In this article the authors present the process of elaborating and content validating a research instrument, which resulted in a questionnaire with three parts, appropriate to the reality of university students in Brazil and Portugal. This instrument aims to collect data that allows the analysis of how cognitive and metacognitive learning strategies are mobilized through digital games.

To present the final instrument was the main purpose of this study, fulfilling one of the objectives established at the beginning of the investigation. With this new instrument, systematic measures can be taken in relation to cognitive and metacognitive strategies and their relationship with digital games, allowing to support research on the subject and reflection on the possible consequences for teaching and learning.

It is hoped that through this empirical investigation it will be possible to characterize how digital games are used in the context of university students; as well as understanding the changes in the digital culture paradigm with the use of digital games in educational contexts.

With these steps, the objective is to relate how cognitive and metacognitive strategies are mobilized in school and out-of-school contexts, allowing an analysis of the formative context of teachers for basic education, promoting a critical reflection of the curricula of undergraduate courses.

\section{ACKNOWLEDGEMENTS}

This work is financially supported by National Funds through FCT - Fundação para a Ciência e a Tecnologia, I.P., under the project UIDB/00194/2020.

The second author work is funded by national funds (OE), through University of Aveiro, in the scope of the framework contract foreseen in the numbers 4, 5 and 6 of the article 23, of the Decree-Law 57/2016, of August 29, changed by Law 57/2017, of July 19.

\section{REFERENCES}

[1] C-C. Chang, CA. Warden, C. Liang and G-Y, Lin. "Effects of digital game-based learning on achievement, flow and overall cognitive load". Australasian Journal of Educational Technology, 34 (4).2018. Doi: https://doi.org/10.14742/ajet.2961

[2] MG. de Jesus and LR. Alves. "Funções Executivas e Jogos Digitais no Contexto Universitário: Uma Revisão Integrativa da Literatura”. Anais do Seminário Tecnologias Aplicadas a Educação e Saúde. Retrieved from: https://revistas.uneb.br/index.php/staes/article/view/8212/5284. 
[3] L. Alves. "Videojogos e aprendizagem: mapeando recursos". In: AAA. Carvalho (Org.). Aprender na era digital: jogos e mobile-learning. Portugal: De Facto Editores, 2012. p.11-28.

[4] L. Alves, IJ. Coutinho (Orgs.). "Jogos digitais e Aprendizagem: Fundamentos de uma prática baseada em evidências". Campinas: Papirus, 2017.

[5] S. Egenfeldt-Nielsen. "The challenges to diffusion of educational computer games". Leading Issues in Games Based Learning, v. 141, 2010. Retrieved form:

https://www.researchgate.net/publication/228793987_The_challenges_to_diffusion_of_educationa I_computer_games

[6] K. Kapp, I. Blair and R. Mesch, The gamificacion of learning and instruction fieldbook: ideas into practice. San Francisco, Wiley. 2014.

[7] L. Pombo and MM. Marques. "The potential educational value of mobile augmented reality games: The case of EduPARK app". Education Sciences, v. 10, n. 10, p. 287, 2020. Doi: https://doi.org/10.3390/educsci10100287

[8] FSC. Pimentel. "Estudo Bibliométrico sobre Games e Educação nos anos 2010 a 2018". Relatório Projeto de iniciação Científica. Maceió, UFAL, 2020. 22 p.

[9] FSC. Pimentel. A aprendizagem das crianças na cultura digital. $2^{\mathrm{a}}$ ed. rev. e ampl. Maceió: Edufal, 2017.

[10] NM. Góes and E. Boruchovitch. Estratégias de aprendizagem: como promove-las. Petrópolis, RJ: Vozes, 2020.

[11] L. SILVA, L. Estilos e estratégias de aprendizagem de estudantes universitários. 2012. Dissertação (Mestrado em Psicologia Escolar e do Desenvolvimento Humano) - Universidade de São Paulo, São Paulo, 2012.

[12] J. Madruga and P. Lacasa. "Processos cognitivos básicos nos anos escolares". In: C. Coll, J. Palacios and A. Marchesi. (org). Desenvolvimento psicológico e educação. Porto Alegre: Artes Médicas, 1995, p. 205-218.

[13] J. Flavell, P. Miller and S. Miller. Desenvolvimento cognitivo. Porto Alegre: Artmed, 1999.

[14] C. Maraschin, R. Kroeff and P. Gavillon. Oficinando com jogos digitais: experiências de aprendizagem inventiva. Curitiba, PR: CRV, 2017.

[15] S. Lucena. Cultura Digital, Jogos Eletrônicos e Educação. 1. ed. Salvador: EDUFBA, 2014.

[16] J. McGonial. A realidade em jogo - por que os games nos tornam melhores e como eles podem mudar o mundo. Rio de Janeiro: BestSeller, 2012.

[17] M. Prensky. Digital game-based learning: practical ideas for the application of digital game-based learning. St. Paul, MN: Paragon House, 2007.

[18] J. Nery Filho and AC. De Oliveira. "Jogos digitais como um aliado para educação: um estudo de caso do Assasins Creed-origins nas aulas de história". In: I. Fayos and M. Piquer. Civilización Digital y Pedagogías Emergentes a partir de las Nuevas Tecnologías, v. 47, 2019. Retrieved: https://www.researchgate.net/publication/339079887_JOGOS_DIGITAIS_COMO_UM_ALIADO_ PARA_EDUCACAO_UM_ESTUDO_DE_CASO_DO_ASSASINNS_CREED_ORIGINS_NAS_AULAS_DE_HISTORIA

[19] D. Ramos and D. Cruz. Jogos digitais em contextos educacionais. Curitiba: CRV 2018.

[20] L. Alves. "Prefácio: jogos digitais e educação: uma história de implicação e desejo". In: D. Ramos and D. Cruz. Jogos digitais em contextos educacionais. Curitiba: CRV 2018.

[21] L. Santaella and M. Feitoza. Mapa do jogo: a diversidade cultural dos games. São Paulo: Cengage Lerning, 2009.

[22] U. Flick. Introdução à pesquisa qualitativa. Porto Alegre: Artmed, 2009.

[23] RK. Yin. Case study research: Design and Methods (5th ed., Issue May). Sage Publications. 2014

[24] G. Schraw and RS. Dennison. "Assessing metacognitive awareness". Contemporary Educational Psychology, 1994. 19(4), 460-75. Doi: https://doi.org/10.1006/ceps.1994.1033 
[25] RN. Lima Filho and AL. Bruni. "Metacognitive Awareness Inventory: Tradução e Validação a partir de uma Análise Fatorial Confirmatória". Psicologia: ciência e profissão, v. 35, n. 4, p. 1275-1293, 2015. Doi: http://dx.doi.org/10.1590/1982-3703002292013

[26] R. Bártolo-Ribeiro, MR. Simões and LS Almeida." Metacognitive Awareness Inventory (MAI): Adaptação e Validação da versão Portuguesa". Revista Iberoamericana de Diagnóstico y Evaluación e Avaliação Psicológica. RIDEP, 2016, 42(2), 143-159. Retrieved from: https://aidep.org/sites/default/files/articles/R42/Art12.pdf

[27] RN. Lima Filho. Empreendendo sobre o empreender e pensando sobre o pensar: um estudo sobre características empreendedoras e metacognição. 2013. 145 f. Tese (Doutorado em Administração). Escola de Administração. Universidade Federal da Bahia, Salvador, 2013.

[28] J. Zumbach, L. Rammerstorfer and I. Deibl. "Cognitive and metacognitive support in learning with a serious game about demographic change". Computers in Human Behavior. V. 103. 2020. p. $120-$ 129. Retrieved from: https://www.sciencedirect.com/science/article/pii/S0747563219303607

[29] J. Kitzinger. "The methodology of focus group: the importance of interaction between research participants". Sociol Health IIIn. 1994;16(1):103-20. Retrieved from: https://onlinelibrary.wiley.com/doi/pdf/10.1111/1467-9566.ep11347023 